\title{
Pathological anatomic changes among laboratory rats in case of experimental infection with the larvae of the nematode Eustrongylides excisus (Nematoda: Dioctophymatidae)
}

\author{
S. L. Honcharov \\ sergeyvet85@ukr.net \\ National University of Life and Environmental Sciences of Ukraine, \\ 16 Polkovnyka Potekhina str., Kyiv, 03041, Ukraine
}

The aim of the research was to model the experimental infection in laboratory rats with the larvae of the nematodes Eustrongylides excisus and documenting the macroscopic changes in organs and tissues of the animals. With a purpose of creating the best conditions for the nematodes larvae's survival the animals were divided into 4 groups. The first group included intact animals. The rats of groups II and III were orally given the $1 \%$ chlorine hydride solution in the amount of 0.5 and $1 \mathrm{ml}$ respectively. Group IV was a control. The rate of the larvae survival in groups I, II and III counted, respectively, 18, 38 and $52 \%$ of the general amount of the larvae put into the organisms of the rats. Among the invaded rats next changes of the clinical conditions were noticed: general weakness, absence of appetite, pain and tension in the abdominal wall etc. After euthanasia and followed autopsy the symptoms of serofibrous ( $20 \%$ of the invaded animals) and fibrinopurulent $(66.6 \%)$ peritonitis were noticed. It also showed the signs of the enteral failure syndrome $(73.3 \%)$ and the abdominal layers adhesion (86.6 \%). Microabscesses under the liver capsule were noticed as well, in $26.6 \%$ of the experimentally infected rats. Pathological changes in the thoracic cavity organs, in part in the heart (pericard and heart sac hemorrhages) and in the lungs (congestive hyperemia and pulmonary edema) have been found in $60 \%$ cases, and in kidneys in $73.3 \%$ cases. Symptoms of catarrhal and hemorrhagic gastritis were observed. The positive correlative connection between the parasitic survival percentage in the organisms of rats and the depth and difficulty of the pathological process was determined.

Key words: Eustrongylides excisus, rats, experimental invasion, autopsy, pathological anatomic changes, peritonitis

It is known that the parasites develop the closest connection with the hosts if they are located in the animal tissues. In such cases, the negative impact on homeostasis of the host's organism is felt the most, because of mechanic damages of the tissues, metabolic and immune imbalance often followed by significant clinical signs and high lethality. The larvae of the Dioctophymatidae family nematodes are those kinds of parasites affecting fishes [3]. The larvae of the Eustrongylides excisus, Jägerskiöld, 1909, are the nematodes from the Dioctophymatidae line, potentially threatening for human health [16]. This species was described and grounded by Egersheld in 1909 as a result of analyzing the nematodes discovered in the glandular stomach of the Phalacrocorax birds [14]. Eustrongylides spp. were qualified as a zoonotic parasite, meaning that it is potentially threatening for humans. The invasion takes place in case of consuming fish or fish products that were not thermally treated enough $[21,27]$.
This species of nematodes is very common for natural waters and artificial reservoirs of Europe, Asia, Northern and Southern Americas. The E. excisus nematodes were reported to have been registered in Serbia, Turkey, Brazil, the USA, Italy, Iran, Azerbaijan, Czech Republic, Russia and Ukraine [3, 9, 15, 18, 22-25].

$E$. excisus nematode is a typical bio tapeworm with a complex development cycle. Fish-eating water birds from the Ciconiiformes, Anseriformes, Gaviiformes and Pelecanoformes families are the main definitive hosts [23]. Intermediate hosts are water oligochaeta from the Tubificidae and Lumbriculidae family, in which the hosts are developed during the first and the second larval periods [14, 15]. Predatory fishes can also take part in the E. excisus development cycle, in part Esocidae, Percidae, Gobiidae, Siluridae, Acipenseridae etc. [3, 19, 20, 23].

According to [14], the larvae of the E. excisus nematode were discovered in the gastrointestinal tract of the Caspian seal (Pusa caspica, Gmelin, 1788). The inva- 
sion intensiveness was from a few nematodes to a few dozens of them. Helminthes were found in the stomach lumen or deeply penetrated into the gastrointestinal wall with the main end [14]. Among the fish-eating birds with the high levels of invasion intensiveness it was possible to determine gastrointestinal wall perforations and different forms of peritonitis as a consequence of the secondary microbial flora getting out of the gastrointestinal canal, which is often deadly. The intestinal tract obturation with the parasites of this species was also reported possible [7].

There were the first report about the natural invasion of a human with the Eustrongylides spp. nematodes. The consumers of fishes and fish products that had not been thermally treated enough were invaded with the eustrongylidosis agents [12]. These invasions characterized with gastritis and intestine perforations [8]. If the hollow viscera of the gastrointestinal canal are perforated, the chyme can get into the abdominal cavity, causing inflammatory processes, usually diffuse or local peritoneum inflammations.

Peritonitis is characterized by the systematic inflammatory process and the development of infective and destructive processes in the abdominal cavity organs followed by the development of the abdominal sepsis. In most cases peritonitis is a secondary pathology, a complication of the main disease or injury that led to the primary site of disease - inflammatory or traumatic organ destruction - occurrence [4].

There are not so many diseases that can be deadly for the individual as a bridging or a definitive host. But regarding the ability of $E$. excisus nematodes to traumatize the abdominal wall and intestine, there is a risk not only for the health but for the life of the infected host.

The aim of this research was to reproduce eustrongylidosis in rats with the description of all the pathological processes among the researched animals affected by Eustrongylides.

\section{Materials and Methods}

The experimental analysis was conducted on 20 nonlineal laboratory rats of the same age (3.5 months), with the body mass $190-230 \mathrm{~g}$. The experiment was held in June. The researched animals were kept in the vivarium of the Mykolaiv regional state laboratory of the State Service of Ukraine for Food Safety and Consumer Protection in separated cages with perforated bottoms to avoid coprophagy. The average air temperature in the room was $19^{\circ} \mathrm{C}$. In between the stagers of the research the rats were fed according to the following nutrition plan: grain mix $-35 \%$, wheat bread $-15 \%$, cow milk - $25 \%$, zoogenic foods (meat, bone and fish scraps) $-9.5 \%$, greens and succulent foods - $15 \%$, salt $-0.5 \%$. The animals were given water from automatic waterers. Food and water access was ad libitum.

The laboratory rats were divided by the analogical principle into 4 groups with 5 animals in each group. The first group was invaded with the $E$. excisus larvae. Each animal was given $0.5 \mathrm{ml}$ of normal saline before $10 \mathrm{E}$. excisus nematodes were transmitted through the stomatogastric catheter. The rats of group II, before the deliberate invasion with 10 living larvae (L3-L4) was given $0.5 \mathrm{ml}$ of $1 \%$ chlorine hydride solution through the stomatogastric catheter. Group III was given $1 \mathrm{ml}$ of $1 \%$ hydrochloric acid solution through the stomatogastric catheter and the same number of larvae. Rats of group IV was a control and received only $0.5 \mathrm{ml}$ of normal saline. The larvae of $E$. excisus nematodes were selected from perch (Perca fluviatilis) caught in the waters of the Dnipro-Buh estuary within the administrative boarder of the Mykolaiv region. Before the catheter insertion, the nematode larvae soaked with normal saline were put into the catheter's distal part with ophthalmological pincers not less than $0.5 \mathrm{~cm}$ away from the edge. The catheter was connected with an injector, containing the mentioned amount of the chlorine hydride to wash the preliminarily put parasitic larvae out of the catheter into the stomach cavity. Chlorine hydride injecting manipulations were repeated up to day 3 , including that date.

The observations lasted 5 days. As the waiting term passed by, the animals were euthanized with the thiopental sodium solution $(0.015 \mathrm{~g}$ of the solution to $1 \mathrm{~kg}$ of the weight) and subjected to the pathological anatomical autopsy. The number and percentage of the surviving larvae in the organisms of rats was defined, pathological and anatomical changes in organs and tissues were rated.

The described method allows to invade with the defined number of parasitic larvae and to conduct the biological probe with the most accommodative disease reproduction laboratory models - rats. This method can also be used in case of invasion with those kinds of parasites that could be mechanically fractured with teeth which makes it impossible to invade the laboratory animals by feeding.

All the researches were conducted in accordance with: the Council of Europe Convention for the Protection of Vertebrate Animals used for Experimental and other Scientific Purposes (ETS123) established on 18.03.1986; the EU Directive 2010/63/EU, the European Union (EU) legislation "on the protection of animals used for scientific purposes"; The Law of Ukraine dated 21.02. 2006 № 3447-IV (revised version 22.06.2017 no. 2120-VIII) "On the Protection of Animals from Brutal Treatment".

The amount of the crude protein was measured biuret reaction, and the proportion of its fractions was measured by electrophoresis in the polyacrylamide gel. Student's $t$-test with a value level $P \leq 0.05$ was used to value the differences between the selected groups. The research results are represented as a set of the average values and mean-square errors $M \pm m$.

\section{Results and Discussion}

\section{General clinic changes}

The invaded animals started to show apathy on the second day, they had appetite decrease or refused to eat at all. The majority of the invaded animals showed low mobility and tried to hide in darker areas. Their hair was matted and slipping. Clinic examination showed accelerated breathing. It is necessary to note that chest breathing was dominant 2-3 days after the invasion, the chest excursion was clearly visible. Light palpation of the abdominal wall showed pain and tension, but reaching the $5^{\text {th }}$ day of the experiment the rats' reaction on palpation was not so significant. Starting from the $3^{\text {rd }}$ day of 
the experiment the researched rats showed some signs of specific body dislocation - the rats bent to decrease the abdominal wall tension, and to lower pain intensiveness as a consequence. At the beginning of the second day of the experiment auricular hyperemia was found. Auriculars turned red, the local temperature increased, the vascular pattern became more visible. Starting from the day 3-4 forelimbs and hind limbs were shown to be cold. Cyanotic discoloration affected auriculars and skin coverings. Some animals also showed signs of movement coordination disorders - ataxia - they were moving in their cages swinging side to side. It is necessary to notice that during the examination of some animals the fragments of dried blood were discovered in the turbinated bone, as well as red exudates elements on the wings of the nose. The daily cleaning showed the decrease of fecal masses starting from the day 2 , probably related to the food consummation decrease as the pathological process got deeper.

\section{Macroscopic changes in organs and tissues}

Euthanasia and pathological anatomical autopsy showed inflammatory processes of the parietal and visceral abdominal layers which are morphologically determined by significant hyperemia and edema of the connective tissue elements. Peritoneum vessels are characterized as visibly full-blooded. A small amount of turbid serous exudates $(0.2-0.8 \mathrm{ml})$ was found in the abdominal cavity. Bloody exudate with the elements of fibrin was noticed in the abdominal cavity of the animals with the highest level of the larvae survival, and as a consequence, the biggest pathological impact on the organism. Fibrin was deposited on the surface of the serous membrane of the bowel and internal organs, including the omentum, in the form of filaments and flakes. After the removal of these layers with pincers the visceral membrane was found to be less glossy, getting duller. A certain amount of fibrin in the form of filaments, flakes and grains was detected in the exudate of the abdominal cavity. These pathological changes are typical for serofibrous peritonitis (table 1).

The symptoms of this pathology were discovered in three samples (60\%) from the group I and in one sample of the group II. Autopsy discovered the E. excisus nematode larvae on the gastrointestinal canal, they showed vital signs (fig. 1).

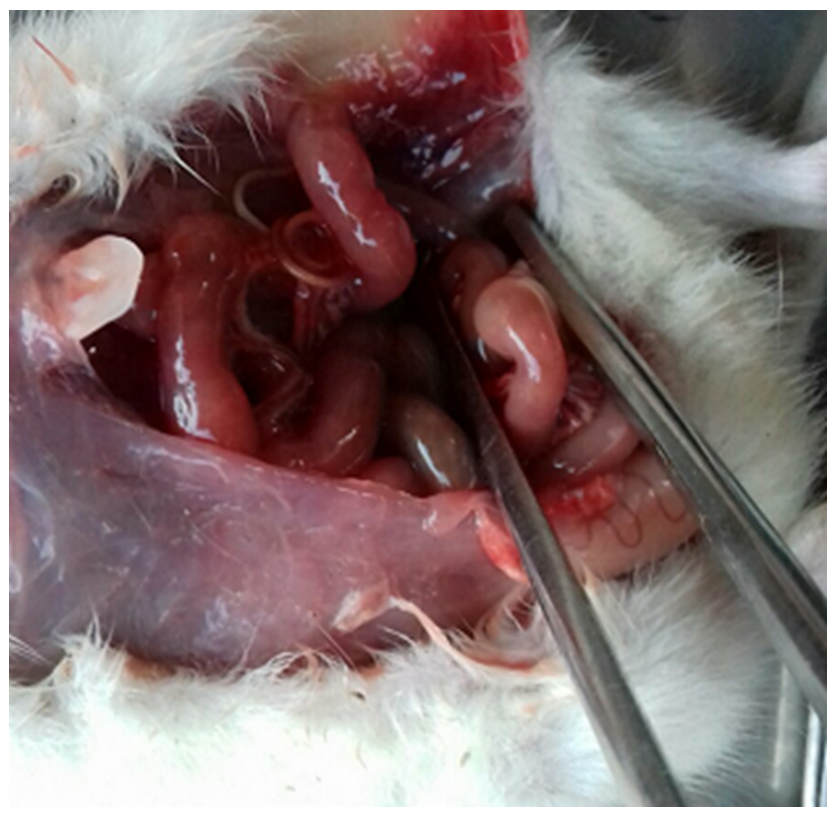

Fig. 1. The symptoms of diffusive peritonitis on the rat invaded with eustrongylidosis. Eustrongylides excisus nematode larva is clearly visible

The intestinal mucosa was anisochromatic pink, fragmentally covered with small hemorrhages. Intestinal wall was swollen, parietal peritoneum and bowel adhesion were noticed, in most cases they were caused by fibrinous deposits. Abdominal layers adhesion was noticed in 3 samples $(60 \%)$ of the group I and all 5 samples $(100 \%)$ of the groups II and III. Fibrinopurulent peritonitis was characterized by the synechial process on the starting stage and the adhesion of the gut loops into a single conglomerate.

When moving the gastrointestinal canal, the adhesions were relatively easy to stratify, small interloop abscesses were noticed in between of them. At the edge of the intestinal wall large layers of fibrin were observed. What is significant, in severe forms of peritonitis fibrin was colored bright yellow, as in the lighter forms it was white, sometimes with a yellowish tinge.

Table 1. Pathological changes found in the organisms of laboratory rats experimentally invaded with Eustrongylides excisus nematodes

\begin{tabular}{|c|c|c|c|c|}
\hline Clinical signs of the pathological process & $\begin{array}{c}\text { Group I } \\
\text { Total } n=5\end{array}$ & $\begin{array}{c}\text { Group II } \\
\text { Total } n=5\end{array}$ & $\begin{array}{l}\text { Group III } \\
\text { Total } n=5\end{array}$ & $\begin{array}{l}\text { Group IV } \\
\text { Total } n=5\end{array}$ \\
\hline Symptoms of the serofibrous peritonitis, $n(\%)$ & $3(60)$ & $1(20)$ & Not found & Not found \\
\hline Symptoms of the fibrinopurulent peritonitis, $n(\%)$ & $1(20)$ & $4(80)$ & $5(100)$ & Not found \\
\hline Micro abscesses on the liver surface, $n(\%)$ & $1(20)$ & $1(20)$ & $2(40)$ & Not found \\
\hline Abdominal layers adhesion, $\mathrm{n}(\%)$ & $3(60)$ & $5(100)$ & $5(100)$ & Not found \\
\hline Symptoms of the enteral failure syndrome, $\mathrm{n}(\%)$ & $2(40)$ & $4(80)$ & $5(100)$ & Not found \\
\hline Significant pathologies of the chest cavity organs, $n(\%)$ & $2(40)$ & $2(40)$ & $4(80)$ & Not found \\
\hline Symptoms of pathological changes in kidneys, $n(\%)$ & $2(40)$ & $4(80)$ & $5(100)$ & Not found \\
\hline
\end{tabular}

Note. Group I are intact animals. Groups II and III were given the $1 \%$ hydrochloric acid solution p.o. in the amount of 0.5 and 1 mI respectively. Group IV is a control group, injected with $0.5 \mathrm{ml}$ of normal saline. 


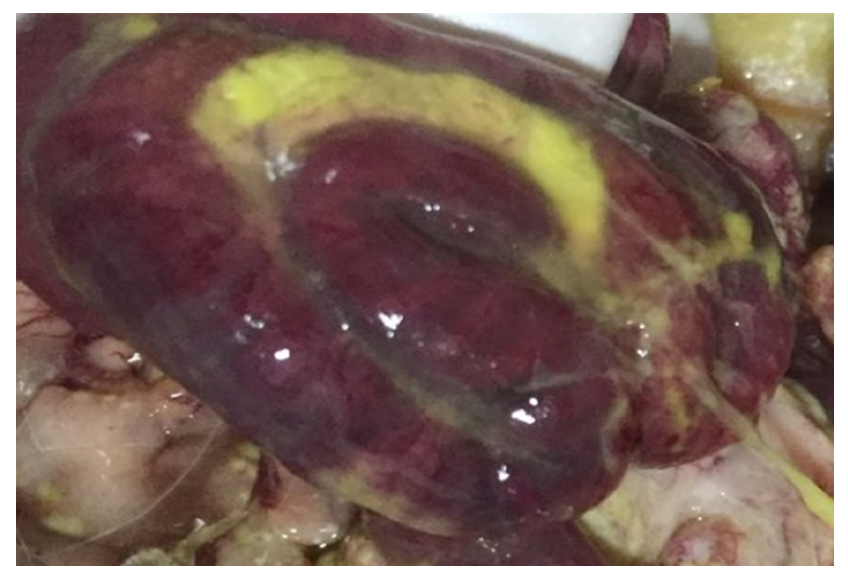

Fig. 2. The small intestine loop of the invaded rat with fibrinopurulent peritonitis

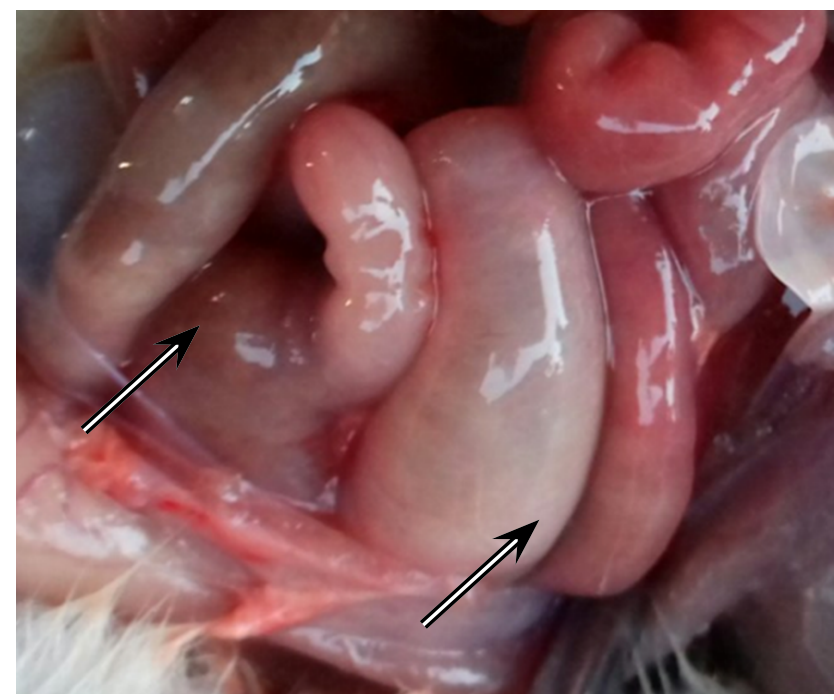

Fig. 3. The intestine areas of the rat, deformed by gases and peritonitis' content

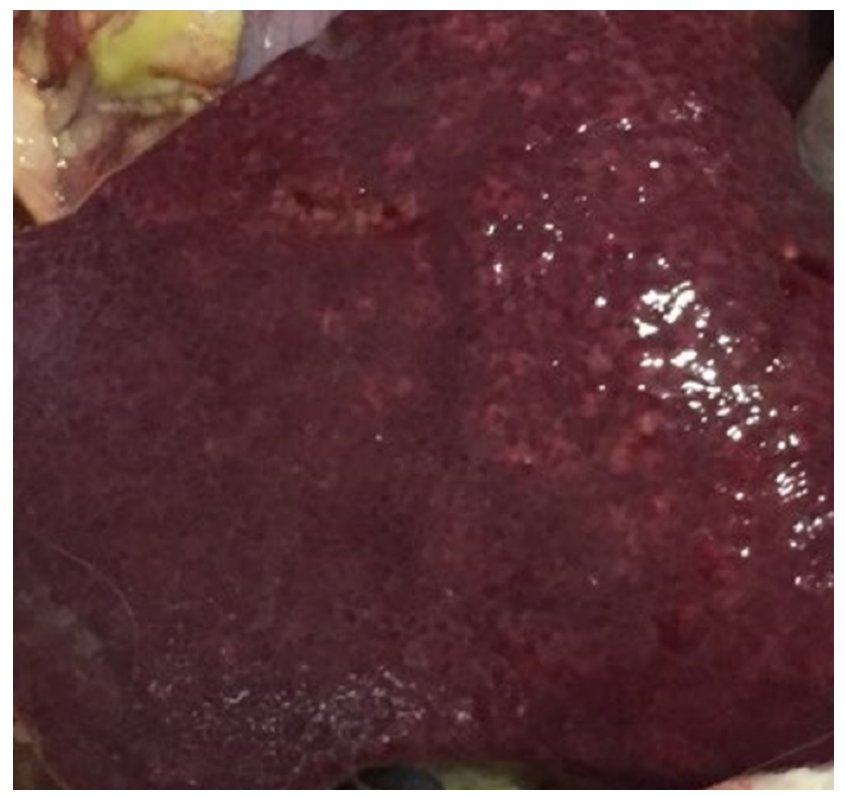

Fig. 4. Diaphragmatic liver surface of the rat with peritonitis. A large amount of micro abscesses is clearly visible
The color of the visceral lining of the intestines ranged from light pink to dark red with cyanotic discoloration. Minor dot and strip hemorrhages could be observed. Vascular branches vascularizing the intestinal wall were dilated, filled with blood, in contrast with the surrounding tissues. Symptoms of fibrinopurulent peritonitis were noticed in one sample $(20 \%)$ of the group I, 4 samples (80\%) of the group II and 5 samples (100\%) of the group III. The surface of the intestines is covered with grey-brown plaque, giving it a specific dimness (fig. 2).

Pathological anatomical autopsy showed enlargement of the intestines and their overflows with gas and content, apparently caused by its secondary atony (paralytic intestinal obstruction) - the main symptom of peritonitis. The intestines are colored light pink with small dark red segments. The vessels of the serous membrane were low-filled because gas-filled intestines create tense on the wall, displacing blood from the peripheral vessels to the vessels of the mesentery of the intestines, which actually provides their vascularization. This leads to swelling of the tissues of the intestinal wall, microcirculation failure, the increased permeability of capillaries and of the wall itself. The inflammatory processes in mesenteric tissues are clearly visible. Symptoms of the enteral failure syndrome were noticed in 3 samples (60\%) from the group I, and in all 5 samples (100\%) from groups II and III. Hyperemia and inflammatory edema are typical (fig. 3).

Liver tissue examination revealed capsular tension. The incision of the liver parenchyma had a loose texture and the edges extended beyond the capsule of the organ, which is a sign of edema. A large number of abscesses were macroscopically detected under the liver capsule. This pathology was found in all 3 groups: in one sample (20\%) from group I and group II and two samples (40\%) from the group III. Autopsy detected bile duct overflow (fig. 4).

Acute catarrhal and hemorrhagic inflammation was observed during the examination of the hollow organs, in part stomach. The surface of the gastric mucosa was swollen and hyperemic, with a thickened wall. Jelly-like exudate with blood admixtures flew out of the incised stomach wall after palpation. Vasodilation was also observed, creating the "vascular" pattern on the mucosa. Wall perforations, additionally limited by the inflammatory rollers, were noticed mostly on the fundus surface of the stomach. The surface of the gastric mucosa was characterized by the significant amount of the serous mucous exudate, as well as point and strip hemorrhages (fig. 5).

Morphological changes were also noticed in the spleen: in some cases it was wrinkled and decreased, but in most cases the enlargement of it was fixed. The organ pulp was tensed, with a plentiful scarp on the incision, which was characterized by homogeneous smooth texture. Kidneys were characterized by ischemic manifestations in the cortical layer and acute cerebral pyramid congestion, which created a significantly contrast pattern. Kidney pathology was noticed in 2 samples (40 \%) from the group I, group II showed analogical results, in the group III there were 4 samples found to be affected by the kidney pathology, which is $80 \%$ of this group of the researched animals. Chest cavity organs were also noticed to be changed. Lungs, in some cases, were colored from bright pink to light red, they were not uniformly colored and full-blooded, the bronchus incision, when palpated, was characterized by foamy bloody exudates, 
which was an indicator of edema. Heart examination showed point hemorrhages on the inner side of the pericardium, in the deep layers of myocardium and on the epicardium surface. These pathologies were noticed in the samples from groups I and II, 2 samples (40\%) each. The group III was characterized by significant chest cavity organ pathologies in 4 samples, which is $80 \%$ of this group of the researched animals.

\section{Larvae survival}

It has been discovered during the research process that after the injection of the $E$. excisus into the gastrointestinal canal of the intact rats, only 9 larvae were discovered when the waiting time passed by. The surviving index of the parasitic larvae in the organisms of the researched animals from this particular group counted $18 \%$, with an average amount of larvae counting $1.8 \pm 0.13$ nematodes. It is necessary to notice that the autopsy of one sample in this group showed no larvae at all. It apparently means that the parasites could not accommodate in the gastrointestinal canal of the laboratory rat, so they died and eliminated.

Among the researched animals from the group II, that received injections of the $1 \%$ hydrochloric acid solution in the amount of $0.5 \mathrm{ml}$ via stomatogastric catheter and invaded with 10 nematode larvae each simultaneously, 19 living larvae the rats had been invaded by were discovered at the end of the experiment. What is

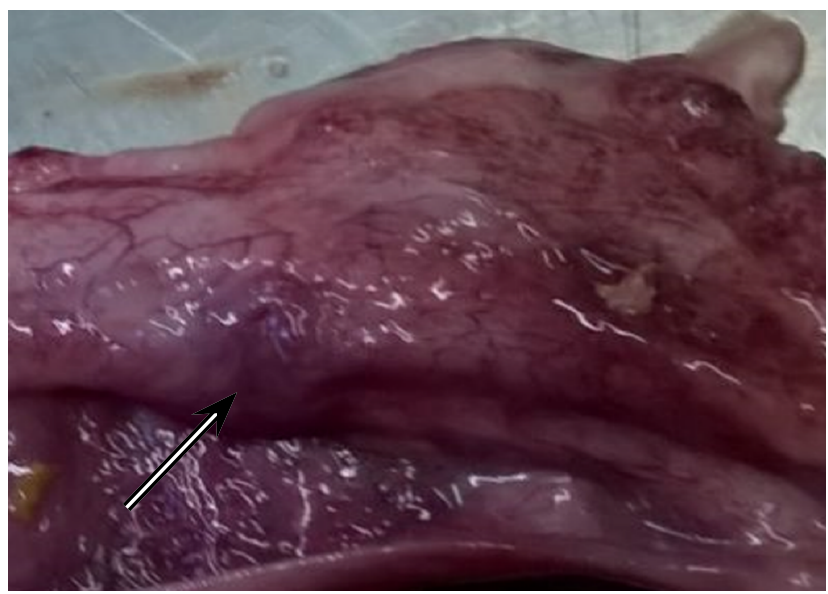

Fig. 5. Gastric mucosa of the rat invaded with Eustrongylides excisus larvae. Inflammatory processes are well-observed, stomach perforations are especially noticeable

significant is that one rat from this experimental group had 7 parasites with the vital signs, which is the top point in the given experiment, as the average index counted $3.8 \pm 0.24$ larvae samples. The general surviving index of the parasites in the organisms of the invaded animals during the experiment counted $38 \%$ (table 2 ).

Table 2. The surviving indexes of the Eustrongylides excisus nematode larvae in the organisms of the laboratory rats in case of experimental invasion

\begin{tabular}{|c|c|c|c|c|}
\hline Numeral characteristics of survival & Group I & Group II & Group III & Group IV \\
\hline Average amount of discovered larvae samples & $1.8 \pm 0.13$ & $3.8 \pm 0.24$ & $5 \pm 0.44$ & Not found \\
\hline Parasitic larvae surviving percentage, \% & 18 & 38 & 52 & Not found \\
\hline
\end{tabular}

Note. Group I are intact animals. Groups II and III were given the $1 \%$ hydrochloric acid solution p.o. in the amount of 0.5 and 1 ml respectively. Group IV is a control group, injected with $0.5 \mathrm{ml}$ of normal saline.

As a result of injecting the animals from the group III with the $1 \%$ chlorine hydride solution in the amount of $1 \mathrm{ml}$ and 50 (for all samples) larvae of the researched nematode, 26 larvae were discovered when the waiting time passed by. The average amount of the parasites in this group counted $5 \pm 0.44$ samples. They showed all the vital signs: they reacted on the mechanical irritators and were mobile. So, the average surviving percentage in this researched group counted $52 \%$. The group IV is a control group, injected with $0.5 \mathrm{ml}$ of normal saline.

Almost every destructive process in the abdominal cavity is followed by inflammatory processes which can, depending on the range of factors, have complications in the form of local or diffuse peritonitis. Microbiological insemination is the main reason of the organism destabilization in the complicated pathogenesis of peritonitis. Significant microbial, autolytic and metabolic disorders mutually deepen one another, which leads to dysfunctions of cardiovascular system, liver, kidneys and other vital organs and systems [1, 5, 6, 13].

Important components of peritonitis in the initial stage are peritoneal hyperemia and formation of the fibrinous deposits on it, in which the microflora is mostly [5]. The main cause of the inflammatory processes' pathogenesis in the abdominal cavity organs is intoxication caused by the bacterial breakdown products (toxins) proteases, biogenic amines, as well as hypovolemia and gastrointestinal tract paresis.

The pathological anatomical autopsy of the experimental rats showed inflammatory processes in visceral and parietal peritoneum, as well as exudates and fibrin deposits in the form of filaments, flakes and grains.

One of the important factors of the progressing pathogenesis of peritonitis is enteral failure syndrome. Reflex sympathetic-tonic suppression of gastrointestinal motility causes bowel atony, as a consequence the intestine is deformed by gases and peritonitis' content [5]. Another typical characteristic - motor-evacuation dysfunction - was established during the autopsy of the rats invaded with the eustrongylidosis agents. The result of bowel overstretching is the development of pain and toxic shock. As a result of the experimental invasion, the dysfunction was characterized by fecal masses and gases accumulated in the lumen of the bowel. 
Mechanic damage of the stomach and bowel walls with E. excisus nematode larvae led to acute inflammations of the walls of the hollow organs of the abdominal cavity, in part stomach. Perforating the stomach and bowel walls the parasite made it possible for the infection to get out of the intestine on the parietal and visceral peritoneum layers.

Toxic and terminal periods of peritonitis are characterized by a significant myocardial contractility with circulatory disorders increasing proportionally to the infection development. Flatulence immobilizes diaphragm and as a consequence affects lung ventilation and causes congestive and inflammatory processes in the chest cavity organs [4]. That is why pathological changes in the heart, such as hemorrhages on its membranes and signs of congestive pulmonary hyperemia, were discovered.

In case of severe peritonitis the pathological process is fully realized, leading to a total exhaustion of the protective and compensatory mechanisms [5]. Such processes can be observed macroscopically, suppuration is formed between the bowel loops and omentum, numerous micro abscesses occur under the liver capsule $[10,18]$. Such pathological changes among rats with peritonitis are typical for this pathology. Abscess formation in the organisms of the rats leads to the infection persistence in the body tissues.

Paralytic obstruction of the gastrointestinal tract makes nutrition impossible as a consequence it leads to metabolic disorder, fast exhaustion and electrolyte imbalance.

The research found positive correlation between the parasitic surviving percentage in the organisms of rats and the dept and difficulty of the pathological process, which can be partly explained by the biological characteristics of the agent and the parasitic strategy of the E. excisus nematode, which uses fish-eating and predatory birds as definitive hosts in most cases [23]. According to the scientific data the $\mathrm{pH}$ level of the gastric acid of certain predatory and fish-eating birds counts 0.7-1.0. This significant physiological characteristic makes it possible for them to digest bones, gristles, scales and other solid elements of the fish body that are hard to digest. The high $\mathrm{pH}$ of the gastric acid of the fish-eating birds also allows them to use the tissues of hydrobionts for nutrition, even in case of major autolysis [2].

\section{Conclusion}

To sum up, the results of the experimental research make it possible to conclude that the invasion of the laboratory rats with the eustrongylidosis agents leads to complicated pathological conditions. The given parasites are potentially threatening for humans, as humans are also at risk of being invaded. The detailed analysis of the agent's biology, of its spreading and changes in the organisms of unspecific hosts is a question of present interest in monitoring the invasive diseases of the fishes in natural waters and artificial reservoirs.

\section{Prospects for Further Research}

Of great interest is the study of morphological and biochemical blood parameters of infected animals.
1. Abdullaev EG, Babyshin VV, Novikov YuA., Gusev AV, Malakhov NB. Peritonitis, A practical training manual. Vladimir, Publishing VIGU. 2014: 144 p. (in Russian)

2. Bessarabov BF, Ostapenko VA. Predator birds. Diagnosis, treatment and prevention of diseases; Content Methods, teaching aid. Moscow, "Aqua-print”. 2011: 256 p. (in Russian)

3. Branciari R, Ranucci D, Miraglia D, Valiani A, Veronesi F, Urbani E, Vaglio G, Pascucci L, Franceschini R. Occurrence of parasites of the genus Eustrongylides spp. (Nematoda: Dioctophymatidae) in fish caught in Trasimeno lake, Italy. Italian Jour. of Food Safety. 2016; 5(4): 206-209. DOI: 10.4081/ijfs.2016.6130.

4. Budasheev VP, Grigoryev EG, Tsibikova EN, Lepekhova SA. Modeling of peritonitis in an experimental setting. Bulletin of the All-Russian Scientific Research Center, Siberian Branch of the Russian Academy of Medical Sciences. 2011; 6(58): 143-147. (in Russian)

5. Buyne OR, Bleichrodt RP, Verweij PE, Groenewoud HMM, Goor H, Hendriks TA. Peritonitis model with low mortality and persisting intra-abdominal abscesses. International Journal of Experimental Pathology. 2006; 87(5): 361-368. DOI: 10.1111/j.13652613.2006.00488.x.

6. Chernjadev SA, Bulaeva El, Kubasov KA. Pathogenetic aspects of intestinal paresis in peritonitis. Dental problems, Yekaterinburg, UMMU. 2016; 12(4): 84-89. DOI: 10.18481/2077-7566-2016-124-84-89. (in Russian)

7. Cole R. Eustrongyloidosis. In: Field Manual of Wildlife Diseases. General Field Procedures and Diseases of Birds. 2013; 29: 223-228.

8. Deardorff TL, Overstreet RM. Seafood-transmitted zoonoses in the United States: the fishes, the dishes, and the worms. In: Microbiology of Marine Food Products (ed. by D. R. Ward \& C. R. Hackney). New York. 1991: 211-265. DOI: 10.1007/978-1-4615-3926-1 9.

9. Fedorov NM, Firsov NF, Soloviev NA. Veterinary and sanitary examination in river perch with Eustrongylidosis. Veterinary $\mathrm{Pa}$ thology. 2014; 3-4: 68-73. (in Russian)

10. Gadelha DNB, Melo MCSC, Oliveira TKB, Brandt CT. Autogenous fecal peritonitis in Wistar rats with permanent bilateral carotid occlusion. Morbidity, mortality and microbiological response. Acta Cir. Bras. 2013; 28(4): 299-306. DOI: 10.1590/ S0102-86502013000400010.

11. Goncharov SL, Soroka NM, Pashkevich IY, Dubovyi Al, Bondar AO. Infection of Predatory Fish with Larvae of Eustrongylides excisus (Nematoda, Dioctophymatidae) in the Delta of the Dnipro River and the Dnipro-Buh Estuary in Southern Ukraine. Vestnik Zoologii. 2018; 52(2): 137-144. DOI: 10.2478/vzoo-2018-0015.

12. Guerin PF, Marapendi S, Grail SL. Intestinal perforation caused by larval Eustrongylides. Morb. Mort. Week. Rep. 1982; 31: 383-389.

13. Ito $Y$, Kinashi H, Katsuno T, Suzuki Y, Mizuno M. Peritonitis-induced peritoneal injury models for research in peritoneal dialysis review of infectious and non-infectious models, Renal Replacement Therapy. 2017; 3(16): 1-10. DOI: 10.1186/s41100-017-0100-4.

14. Karmanova EM. Dioctophymidea of animals and man and the diseases caused by them. Moscow, Nauka Publishing. 1968: 383 p.

15. Lichtenfels JR, Stroup CF. Eustrongylides sp. (Nematoda: Dioctophymatoidea): First Report of an Invertebrate Host (Oligochaeta: Tubificidae) in North America. Proc. Helminthol. Soc. Wash. 1985; 52(2): 320-323. Available at: http://bionames.org/ bionames-archive/issn/0018-0130/52/320.pdf

16. Ljubojevic D, Novakov N, Djordjevic V, Radosavljevic V, Pelic M, Cirkovic M. Potential parasitic hazards for humans in fish meat. Procedia Food Science. 2015; 5: 172-175. DOI: 10.1016/j.profoo. 2015.09.049.

17. Melo FTV, Melo CSB, Nascimento LCS, Giese EG, Furtado AP, Santos JN. Morphological characterization of Eustrongylides sp. larvae (Nematoda, Dioctophymatoidea) parasite of Rhinella marina (Amphibia: Bufonidae) from Eastern Amazonia. Rev. Bras. Parasitol. Vet., 2016; 25(2): 7-12. DOI: 10.1590/S198429612016024. 
18. Melo MCSC, Gadelha DNB, Oliveira TKB, Brandt CT. Severe autogenously fecal peritonitis in Wistar rats with permanent bilateral carotid occlusion. Response to intra peritoneal moxifloxacin combined with dexamethasone. Acta Cir. Bras. 2014; 29(2): 76-81. DOI: 10.1590/S0102-86502014000200001.

19. Metin S, Didinen Bİ, Boyaci YO, Kubilay A, Emre N, Didinen H, Emre Y. Occurrence of Eustrongylides excisus, Jägerskiöld, 1909 larvae (Nematoda: Dioctophymatidae) in Pikeperch (Sander lucioperca L.) in Lake Eğirdir. Süleyman Demirel Üniversitesi Eğirdir Su Ürünleri Fakültesi Dergisi. 2014; 10(1): 20-24. DOI: 10.22392/egirdir.246371.

20. Moshu A. Helminths of fish ponds between the rivers Dniester and Prut, potentially dangerous to human health. Kishineu, Eco-Tiras, 2014: 88 p. (in Russian)

21. Narr LL, O'Donnell JG, Libster B, Alessi P, Abraham D. Eustrongylidiasis - a parasitic infection acquired by eating live minnows. J. Am. Ost. Assoc. 1996; 96(7): 400-402. DOI: 10.7556/jaoa.1996.96.7.400.

22. Noei MR, Ibrahimov S, Sattari M. Parasitic worms of the Persian sturgeon, Acipenser persicus Borodin, 1897 from the southwestern shores of the Caspian Sea. Iranian Jour. of Ichthyology. 2015; 2(4): 287-295. DOI: 10.22034/iji.v2i4.107.
23. Novakov N, Bjelic-Cabrilo O, Circovic M, Jubojevik D, Lujic J, Davidov I, Jovanovic M. Eustrongylidosis of European Catfish (Siluris glanis). Bulg. J. Agric. Sci. 2013; 19(1): 72-76. Available at: https://www.agrojournal.org/19/01-13s.pdf

24. Pazooki J, Masoumian M, Yahyazadeh M, Abbasi J. Metazoan parasites from freshwater fishes of Northwest Iran. J. Agric. Sci. Technol. 2007; 9: 25-33. Available at: https://jast.modares.ac.ir/ article-23-9130-en.pdf

25. Soylu E. Metazoan Parasites of Perch Perca fluviatilis L. From Lake Sığırcı, Ipsala, Turkey. Pakistan J. Zool., 2013; 45(1): 47-52. Available at: http://zsp.com.pk/pdf45/47-52\%20_7_\%20PJZ-92612\%207-12-12.pdf

26. Spalding MG, Forrester DJ. Pathgenesis of Eustrongylides ig notus (Nematoda: Dioctophymatidae) in Ciconiiformes. Journal of Wildlife Diseases. 1993; 29(2): 250-260. DOI: 10.7589/00903558-29.2.250.

27. Wittner M, Turner JW, Jacquette G, Ash LR, Salgo MP, Tanowitz HB. Eustrongylidiasis - a parasitic infection acquired by eating sushi. N. Engl. J. Med. 1989; 320: 1124-1126. DOI: 10.1056/ NEJM198904273201706.

\title{
Патологоанатомічні зміни у лабораторних щурів за експериментального зараження личинками нематоди Eustrongylides excisus (Nematoda: Dioctophymatidae)
}

\author{
С. Л. Гончаров \\ sergeyvet85@ukr.net
}

Національний університет біоресурсів і природокористування України, вул. Полковника Потєхіна, 16, м. Київ, 03041, Україна

Метою досліджень було змоделювати експериментальне зараження лабораторних щурів личинками нематоди Eustrongylides excisus та задокументувати макроскопічні змін в органах і тканинах піддослідних тварин. 3 метою створення найбільш оптимальних умов для виживаності личинок нематод тварин ділили на 4-и групи. I група - дослідна група рефрерентних тварин, II та III - дослідні групи, яким перорально вводили 1\% розчин соляної кислоти у кількості 0,5 та 1 мл відповідно; IV група — контрольна. Тварин I, II і III груп експериментально заражали личинками нематоди Eustrongylides excisus. Taк, виживаність личинок паразитів у I, II і III групах становила 18, 38 та 52 \% відповідно, від загальної кількості личинок, яких було введено в організм щурів. В інвазованих щурів відмічали зміни клінічного стану: слабкість, відсутність апетиту, болючість та напруженість черевної стінки, тощо. Після проведення евтаназії та наступної автопсії було встановлено ознаки серознофібринозного та гнійно-фібринозного перитоніту. Також відмічали адгезію листків очеревини та утворення мікроабсцесів під капсулою печінки. Відмічали патології органів грудної порожнини, зокрема серця (крововиливи на перикарді та оболонках серця) і легень (явища застійної гіперемії, набряку). Також виявляли ознаки катарального та геморагічного гастриту, перфорації шлункової стінки. Встановлено статистично значущу тенденцію, що із зниженням рівня рН шлункового соку щурів кількість личинок, що вижили в організмі тварин, збільшувалась.

Ключові слова: Eustrongylides excisus, щури, експериментальне зараження, автопсія, патологоанатомічні зміни, перитоніт

Honcharov SL. Pathological anatomic changes among laboratory rats in case of experimental infection with the larvae of the nematode Eustrongylides excisus (Nematoda: Dioctophymatidae). Biol. Tvarin. 2020; 22(1): 3-9. DOI: 10.15407/animbiol22.01.003. 